\title{
Peningkatan Kapasitas dan Inovasi Koperasi Pangan Boga Makmur Menghadapi Era Industri 4.0
}

\author{
Heru Irianto, Sugiharti Mulya Handayani*, Endang Siti Rahayu, Mei Tri Sundari, Setyowati \\ Program Studi Agribisnis, Fakultas Pertanian, Universitas Sebelas Maret \\ Jl. Ir. Sutami No. 36 A Kentingan Surakarta \\ *Corresponding Author: sugihartimulya@ @staff.uns.ac.id
}

\begin{abstract}
ABSTRAK
Revolusi Industri 4.0 memberikan peluang kepada UKM untuk lebih berkembang. Dalam kenyataannya banyak permasalahan internal yang menghambat perkembangan UKM. Permasalahan internal yang sering menjadi penghambat adalah kemampuan pengelolaan keuangan yang rendah dan daya saing produk yang belum maksimal. Kegiatan pengabdian bertujuan untuk meningkatkan kapasitas UKM pangan di era industri 4.0 terutama dalam pengelolaan keuangan dan inovasi kemasan. Kegiatan pengabdian ini dilaksanakan dengan mitra Koperasi Pangan Boga Makmur di Kabupaten Sukoharjo melalui FGD terbatas, pelatihan dan pendampingan. Metode Participatory Rural Appraisal (PRA) digunakan untuk menjamin kegiatan memberikan hasil maksimal. Dengan metode ini peserta diharapkan terlibat penuh dalam kegiatan. Kegiatan pengabdian dilaksanakan dengan memberikan pelatihan dan pendampingan tentang pembukuan keuangan dan pembuatan kemasan yang marketable dan dapat meningkatkan daya saing produk. Pelatihan memberikan banyak manfaat bagi peserta, namun adanya pandemi membuat usaha terhenti, sehingga baru sekitar $10 \%$ peserta pelatihan yang sudah mempunyai pembukuan keuangan dan $30 \%$ yang sudah mempunyai kemasan marketable.
\end{abstract}

Kata kunci: daya saing, kemasan, pengelolaan keuangan, UKM

\section{ABSTRACT}

Industrial Revolution 4.0 provides opportunities for SMEs to develop more. In reality, many internal problems hinder the development of SMEs. Internal problems that often become obstacles are low financial management capability and product competitiveness that has not been maximized. The service activities aim to increase the capacity of food SMEs in the industrial era 4.0, especially in financial management and packaging innovation. This service activity was carried out with partners of the Boga Makmur Food Cooperative in Sukoharjo Regency through limited FGDs, training, and mentoring. To ensure that activities provide maximum results, the Participatory Rural Appraisal (PRA) method is used in these activities. With this method, the participants are expected to be fully involved in the activity. Community service activities are carried out by providing training and mentoring on financial bookkeeping and making marketable packaging that can increase product competitiveness. The training provided many benefits for participants, but there was a pandemic that stopped businesses, only about 10\% of training participants already had financial bookkeeping and $30 \%$ already had marketable packaging.

Key words: competitiveness, packaging, financial management, SMEs

\section{PENDAHULUAN}

Revolusi Industri 4.0 merupakan kemajuan teknologi baru yang mengintegrasikan dunia fisik, digital, dan biologis, dimana terdapat perubahan cara hidup kerja manusia secara fundamental (Hamdan, 2018). Di era revolusi industri 4.0 sumber daya manusia mempunyai kesempatan untuk memiliki keahlian yang sesuai dengan perkembangan teknologi terkini melalui program peningkatan keterampilan (up-skilling) atau pembaruan keterampilan (re-skilling) 
(Rohida, 2018). Salah satu kelompok yang perlu untuk mendapatkan up-skilling maupun reskilling adalah UKM, karena sebagian besar kelompok tersebut mempunyai keterbatasan baik dibidang teknologi, permodalan maupun pemasaran. Dalam era revolusi industri 4.0, UKM perlu mendapat perhatian lebih. Hal ini sejalan dengan pernyataan Hamdan (2018) bahwa salah satu dampak dari revolusi industri 4.0 adalah peningkatan yang pesat bidang perekonomian khususnya sektor perdagangan dan UKM..

Usaha Kecil dan Menengah (UKM) memiliki peran yang signifikan dan strategis bagi perekonomian Indonesia. Keberadaan sektor ini mampu menjadi kantong penahan dalam situasi darurat. UKM terbukti mampu bertahan bahkan menjadi motor penggerak perekonomian setelah terjadinya krisis ekonomi (Hadiyati, 2011). Peran tersebut berkaitan dengan potensinya yang besar dalam penyerapantenaga kerja, dan Pendapatan Domestik Bruto (PDB) nasional (Munizu, 2013). Kementerian Koperasi dan UKM (2019) menyebutkan bahwa terdapat Usaha Mikro sejumlah 63,5 juta unit, Usaha Kecil sejumlah 783.132 unit, dan Usaha Menengah 60.702 unit. Jumlah serapan tenaga kerja UKM di level nasional mencapai 97\% (Kementerian Koperasi dan UKM, 2017). Selanjutnya, kontribusi UKM terhadap PDB nasional mencapai 60\% (BPS, 2016).

Dalam perkembangannya, UKM nasional menghadapi beberapa permasalahan dan sekaligus tantangan. Permasalahan yang dihadapi oleh UKM di Indonesia meliputi: 1. Aksesabilitas (modal, informasi-teknologi, pasar, dan faktor produksi lainnya), 2. Kualitas SDM rendah, 3. Produktivitas rendah, dan 4. Daya saing rendah (Bismala, 2016; Hartono \& Hartomo, 2016). Liberalisasi ekonomi dan keterbukaan teknologi informasi merupakan ekosistem baru yang harus disikapi dengan baik oleh UKM. Kondisi tersebut memunculkan beragam tantangan yang harus dihadapi oleh UKM, seperti ketatnya persaingan pasar domestik akibat serbuan dari produk luar negeri, rendahnya perlindungan pemerintah terhadap UKM, persaingan di pasar input produksi, dan daya saing produk UKM (Hartono \& Hartomo, 2016). Dengan demikian perlu adanya kegiatan untuk menguatkan faktor-faktor yang pendukung UKM agar mampu bersaing dan berhasil menghadapi permasalahan maupun tantangan tersebut. Faktor-faktor tersebut diantaranya adalah SDM pengelola, permodalan, teknologi dan peralatan, kemampuan manajerial dan pemasaran, kontinuitas bahan baku, dan teknologi informasi (Bismala, 2016).

Salah satu UKM yang berkembang di Kabupaten Sukoharjo adalah Koperasi Pangan Boga Makmur. Koperasi ini merupakan salah satu bentuk CSR dari perusahaan tepung terigu Sri Boga Ratu Raya. Koperasi Pangan Boga Makmur beranggotakan pelaku UKM pangan berbahan dasar tepung terigu. Berdasarkan informasi dari ketua koperasi dapat diketahui bahwa permasalahan yang dialami Koperasi Pangan Boga Makmur secara spesifik adalah anggota yang mengalami kredit macet. Meskipun seiring berjalannya waktu jumlah kredit macet yang dialami anggota kelompok menunjukkan trend menurun, namun untuk pertumbuhan dan perkembangan koperasi kedepan, hal tersebut haruslah diminimalkan. Kredit macet yang dialami oleh Koperasi Pangan Boga Makmur disebabkan oleh faktor internal dan faktor eksternal. Faktor internal terkait dengan problem personal seperti permasalahan ekonomi keluarga, dan karakteristik personal yang tidak disiplin. Faktor eksternal yang saat ini berdampak besar terhadap UKM adalah pandemi Covid 19. Berbagai kebijakan yang ditetapkan pemerintah untuk memutus rantai penyebaran Covid 19 seperti menjaga jarak, larangan berkerumun, pembatasan akses keluar masuk suatu wilayah berdampak besar terhadap anggota Koperasi Pangan Boga Makmur. Untuk itu perlu dilakukan kegiatan untuk meningkatkan kapasitas Koperasi Pangan Boga Makmur.

Kredit macet mengganggu keberlangsungan koperasi yang pada akhirnya akan mengganggu masalah keuangan. Hal ini karena dana tidak bisa bergulir kepada anggota sebagaimana mestinya. Permasalahan ini muncul tidak hanya karena pengelolaan keuangan yang masih belum baik (diindikasikan dengan belum adanya pembukuan keuangan yang benar), tetapi juga karena kurangnya daya saing produk terutama di masa pandemi Covid 19 saat ini. Daya saing yang masih rendah salah satunya disebabkan oleh kemasan yang masih sederhana dan belum marketable.

Kemasan adalah hubungan bentuk, struktur, warna, bahan, gambar, tipografi dan informasi dengan elemen desain visual agar lebih menarik konsumen (Tunky \& Kohardinata, 2016). Pengemasan meliputi kegiatan mendesain dan memproduksi dengan fungsi melindungi produk agar kualitasnya tetap terjaga hingga ke 
tangan konsumen (Erijanto \& Fibrianto, 2018). Anisa (2017) menambahkan bahwa konsumen dalam membeli produk, tidak serta merta untuk konsumsi langsung melainkan dapat sebagai persediaan. Penelitian Ambarwati (2015) menunjukkan bahwa brand image yang terdiri dari citra perusahaan, citra konsumen, dan citra produk secara simultan berpengaruh positif signifikan terhadap minat beli konsumen. Dalam produk makanan merek yang mudah diingat dan mempunyai citra positif akan menjadi prioritas pertama pilihan konsumen (Lidyasuwanti, 2017).

Kegiatan pengabdian masyarakat ini bertujuan untuk membantu anggota Koperasi Pangan Boga Makmur mengatasi masalah keuangan dan meningkatkan daya saing produk. Kegiatan pengabdian tersebut berupa pelatihan tentang pembukuan keuangan dan pelatihan tentang desain kemasan. Pelatihan tentang pembukuan keuangan diberikan kepada anggota koperasi untuk mengatasi masalah keuangan. Pelatihan tentang inovasi desain kemasan produk yang marketable diberikan kepada anggota koperasi untuk meningkatan daya saing produk.

\section{METODE}

Untuk mencapai tujuan kegiatan pengabdian, dalam pelaksanaannya sejauh mungkin melibatkan kelompok mitra untuk berperan aktif sehingga metode yang digunakan adalah Participatory Rural Appraisal (PRA). Menurut (Sidu \& Sugihen, 2007), PRA adalah suatu metode yang menempatkan masyarakat sebagai subjek, perencana, pelaksana, sekaligus sebagai penilai dalam program pemberdayaan. Keterlibatan peserta secara aktif dan menjadikannya sebagai subjek diharapkan akan memberi dampak yang lebih nyata. Dalam pelaksanaannya kegiatan pengabdian masyarakat ini dilakukan melalui FGD terbatas, pelatihan, monitoring dan evaluasi serta pendampingan.

\section{FGD (Focuss Group Disscussion)}

Kegiatan pengabdian diawali dengan FGD terbatas. FGD adalah suatu proses pengumpulan informasi suatu masalah melalui diskusi kelompok. Menurut (Afiyanti, 2008) melalui FGD diharapkan memperoleh masukan atau informasi mengenai suatu permasalahan yang bersifat lokal dan spesifik. FGD dilaksanakan oleh tim pelaksana kegiatan dengan ketua Koperasi Pangan Boga Makmur. Kegiatan FGD bertujuan untuk menggali potensi keterlibatan mitra dan kordinasi pelaksanaan kegiatan.

\section{Pelatihan}

Dalam kegiatan pengabdian masyarakat ini ada dua pelatihan yang diberikan yaitu pelatihan pengelolaan keuangan secara sederhana dan pelatihan pembuatan desain kemasan yang mampu meningkatkan daya saing dan marketable. Kegiatan pelatihan diikuti oleh anggota Koperasi Pangan Boga Makmur dan beberapa orang yang menjadi mitra koperasi (kluster supplier produk yang dipasarkan koperasi).

\section{Monitoring dan Evaluasi}

Untuk melihat dampak sebuah pelatihan, perlu adanya monitoring dan evaluasi. Monitoring dan evaluasi merupakan salah satu langkah yang harus dilakukan setelah pelaksanaan kegiatan pelatihan. Monitoring dan evaluasi berfungsi untuk mengontrol sejauh mana pelatihan diaplikasikan dan melihat sejauh mana pelatihan memberi manfaat. Setelah dilakukan monitoring dan evaluasi, bilamana diperlukan peserta pelatihan diberikan pendampingan.

\section{Pendampingan}

Pendampingan dilakukan untuk membantu mengatasi permasalahan yang muncul terutama yang berkaitan dengan materi pelatihan. Monitoring dan pendampingan dilakukan secara berkala secara daring menggunakan media komunikasi yang disepakati (WA).

\section{HASIL DAN PEMBAHASAN}

Kegiatan pengabdian dilaksanakan dengan melibatkan Koperasi Pangan Boga Makmur sebagai mitra. Koperasi Pangan Boga Makmur adalah koperasi yang dibentuk sebagai CSR perusahaan tepung Sri Boga Ratu Raya. Anggota Koperasi Pangan Boga Makmur adalah para pelaku usaha makanan berbahan tepung yang berdomisili di Kabupaten Sukoharjo. Saat ini anggota koperasi berjumlah 30 orang dengan beraneka macam produk (kue basah, kue kering, roti dan sebagainya).

Sebelum kegiatan dilaksanakan, terlebih dahulu tim pengabdian melakukan pendekatan dan sosialisasi kegiatan dengan Ibu Surati selaku 
ketua koperasi. Komunikasi intensif dilakukan dengan ketua Koperasi Pangan Boga Makmur untuk membahas pelaksanaan kegiatan secara teknis. Dari hasil diskusi disepakati bagaimana bentuk kegiatan, kapan kegiatan dilaksanakan serta apa kewajiban kedua belah pihak. Secara garis besar kegiatan pengabdian ini dilaksanakan dengan memberikan pelatihan pengelolaan keuangan secara sederhana dan pelatihan pembuatan desain kemasan yang mampu meningkatkan daya saing dan marketable.

Untuk menjamin kegiatan pelatihan dapat memberikan manfaat seperti yang diharapkan, narasumber dari pelatihan ini merupakan orangorang yang kompeten di bidangnya. Narasumber untuk pengelolaan keuangan adalah Ibu Mei Tri Sundari, S.P., M.Si yang berpengalaman sebagai pengampu mata kuliah Manajemen Finansial dan Akuntasi Manajemen. Materi tentang desain yang marketable diberikan oleh Ibu Nidyah Widyamurti, S.Sn., M.IKom dari Pusat Studi Pendampingan KUMKM LPPM UNS.

\section{Pelaksanaan Pelatihan dan Karakteristik Peserta}

Berdasarkan kordinasi awal yang telah dilaksanakan antara tim pelaksana kegiatan pengabdian dengan Ibu Surati selaku ketua koperasi mitra disepakati bahwa peserta pelatihan kegiatan pengabdian ini adalah semua anggota Koperasi Pangan Boga Makmur yang berjumlah kurang lebih 30 orang. Namun dikarenakan adanya pandemi Covid 19, semua rangkaian kegiatan yang sudah direncanakan harus disesuaikan. Dalam rangka meminimalkan risiko penyebaran Covid 19 dan mengusahakan kegiatan pengabdian dapat diikuti oleh semua anggota Koperasi Pangan Boga Makmur, tim pelaksana pengabdian menawarkan pelatihan secara daring dengan menggunakan media zoom meeting. Namun tawaran ini tidak bisa disepakati karena adanya beberapa kendala dari pihak mitra. Sebagian besar anggota Koperasi Pangan Boga Makmur berpendidikan terbatas dan belum mempunyai pengalaman menggunakan zoom meeting.

Dengan mempertimbangan berbagai keterbatasan yang ada dan sebagai upaya meminimalkan risiko penyebaran Covid 19, akhirnya disepakati kegiatan pengabdian tetap dilaksanakan secara luring namun dengan jumlah peserta terbatas serta penerapan protokol kesehatan yang ketat. Dalam pelaksanaannya, peserta wajib memakai masker, menjaga jarak (social distancing), pengukuran suhu dengan thermogun dan mencuci tangan dengan sabun atau handsanitizer sebelum kegiatan.

Pelatihan dilaksanakan pada Hari Sabtu, 8 Agustus 2020 bertempat di rumah Ibu Surati sebagai ketua Koperasi Pangan Boga Makmur yang beralamat di Ganggasan RT. 03/05 Demakan, Mojolaban, Sukoharjo. Peserta pelatihan kegiatan ini berjumlah 14 orang, yang terdiri dari anggota Koperasi Pangan Boga Makmur dan mitra koperasi (supplier produk olahan yang dipasarkan koperasi). Karateristik peserta pelatihan dapat dilihat pada Tabel 1 berikut ini.

Tabel 1. Karakteristik peserta pelatihan pengelolaan keuangan sederhana dan pembuatan kemasan

\begin{tabular}{lcccl}
\hline \multicolumn{1}{c}{ Nama } & P/L & $\begin{array}{c}\text { Umur } \\
\text { (tahun) }\end{array}$ & $\begin{array}{c}\text { Pendidikan } \\
\text { (tahun) }\end{array}$ & Jenis Produk \\
\hline Ibu Sularto & $\mathrm{P}$ & 45 & 12 & Roti \\
Bpk Sularto & $\mathrm{L}$ & 50 & 12 & Roti \\
Ibu Sri Miyati & $\mathrm{P}$ & 47 & 12 & Roti \\
Ibu Surati & $\mathrm{P}$ & 56 & 12 & Roti dan snack \\
Ibu Safitri Damayani & $\mathrm{P}$ & 43 & 12 & Peyek \\
Fajar Satriyawan & $\mathrm{L}$ & 25 & 15 & Roti dan snack \\
Ibu Woro Wijayanti & $\mathrm{P}$ & 45 & 15 & Aneka Rengginang \\
Ibu Sri Wahyuni & $\mathrm{P}$ & 66 & 9 & - \\
Ibu Watiyah Srimulyani & $\mathrm{P}$ & 57 & 12 & Snack dan camilan \\
Ibu Siti Rahayu & $\mathrm{P}$ & 57 & 12 & Fried chicken \\
Ibu Feri Indah & $\mathrm{P}$ & 49 & 12 & Rambak dan onde2 ketawa \\
Ibu Siti Chonisah & $\mathrm{P}$ & 40 & 12 & Kue kering \\
Ibu Sri Yanti & $\mathrm{P}$ & 48 & 9 & Catering dan reseller \\
Ibu Surya Maya Sari & $\mathrm{P}$ & 41 & 12 & Snack basah dan kue kering \\
\hline Rata-rata & & 48 & 12 & \\
\hline
\end{tabular}

Sumber : data primer 
Berdasarkan Tabel 1 dapat diketahui bahwa rentang umur peserta pelatihan yaitu 2566 tahun dengan rata-rata 48 tahun. Dilihat dari rata-rata umur, peserta pelatihan termasuk dalam kategori kelompok umur produktif dan potensial untuk mengembangkan usaha. Hal ini sejalan dengan hasil kajian Anwar \& Fatmawati (2018) bahwa usia produktif berpengaruh signifikan terhadap pertumbuhan ekonomi. Apabila dilihat dari lama menempuh pendidikan formal, ratarata peserta pelatihan menempuh pendidikan formal 12 tahun (setara lulus SMA). Berdasarkan karakteristik peserta pelatihan dapat diketahui bahwa tingkat pendidikan peserta pelatihan tidak terlalu tinggi dan ada beberapa peserta yang termasuk kategori lansia. Kondisi ini menjadi kendala pelaksanaan kegiatan secara daring.

Dari Tabel 1 juga dapat dilihat bahwa sebagian besar produk yang dihasilkan oleh peserta pelatihan adalah camilan (kue-kue baik basah maupun kering) berbahan tepung terigu. Hal ini sesuai dengan sejarah Koperasi Pangan Boga Makmur yang terbentuk sebagai bentuk CSR dari perusahaan tepung Sri Boga Ratu Raya. Beberapa peserta pelatihan yang produk utamanya tidak berbahan tepung, merupakan mitra dari Koperasi Pangan Boga Makmur. Semua produk yang dihasilkan oleh anggota Koperasi Pangan Boga Makmur sudah bermerek dan mempunyai kemasan yang relatif baik namun masih perlu diperbaiki untuk meningkatkan daya saing produk.

Berdasarkan Tabel 2 dapat diketahui bahwa produk yang dipasarkan oleh peserta pelatihan sudah mempunyai merek namun hanya beberapa yang desain dan kemasannya sudah marketable. Sebagian besar kemasan yang digunakan masih dalam kategori cukup menarik dan sederhana serta ada satu produk roti yang desain kemasannya sudah menarik tetapi tidak konsisten.

Tabel 2. Karakteristik peserta pelatihan berdasar jenis produk, merek dan kemasan

\begin{tabular}{|c|c|c|c|}
\hline Nama Peserta & Jenis Produk & Merek & Kemasan \\
\hline Ibu Sularto & Roti & Solo Satu & $\begin{array}{lll}\text { Menarik } & \text { tetapi } & \text { tidak } \\
\text { konsisten } & & \\
\end{array}$ \\
\hline Bpk Sularto & Roti & Solo Satu & $\begin{array}{l}\text { Menarik tetapi tidak } \\
\text { konsisten }\end{array}$ \\
\hline Ibu Sri Miyati & Roti & Kharisma & - \\
\hline Ibu Surati & Roti dan snack & Salsabila & Marketable \\
\hline Ibu Safitri Damayani & Peyek & Peyek Bunder & Marketable \\
\hline Fajar Satriyawan & Roti dan snack & Salsabila & Marketable \\
\hline Ibu Woro Wijayanti & $\begin{array}{l}\text { Aneka } \\
\text { Rengginang }\end{array}$ & Jaya Rasa & Cukup menarik \\
\hline Ibu Sri Wahyuni & - & - & - \\
\hline Ibu Watiyah Srimulyani & $\begin{array}{l}\text { Snack dan } \\
\text { camilan }\end{array}$ & Mulia & Sederhana \\
\hline Ibu Siti Rahayu & Fried chicken & Mickey & Marketable \\
\hline Ibu Feri Indah & $\begin{array}{l}\text { Rambak dan } \\
\text { onde2 ketawa }\end{array}$ & Rambak Ayu & Sederhana \\
\hline Ibu Siti Chonisah & Kue kering & Annisa Sari & Sederhana \\
\hline Ibu Sri Yanti & $\begin{array}{l}\text { Catering dan } \\
\text { reseller }\end{array}$ & Bu Jayus & Cukup menarik \\
\hline Ibu Surya Maya Sari & $\begin{array}{l}\text { Snack basah dan } \\
\text { kue kering }\end{array}$ & Surya & Sederhana \\
\hline
\end{tabular}

Sumber : Data Primer

Pelaksanaan Program Pengabdian Kepada Masyarakat

\section{Pelatihan Pengelolaan Keuangan}

Pengelolaan keuangan yang baik dan benar mutlak diperlukan sebuah usaha untuk berkembang. Laporan keuangan seringkali menjadi dasar pemberian bantuan modal ataupun tawaran kerjasama. Laporan keuangan yang baik merupakan indikator usaha berjalan dengan sehat. Namun seringkali masalah pengelolaan keuangan diabaikan pelaku UKM apalagi apabila usahanya masih berskala rumah tangga. Kelemahan UKM berskala rumah tangga adalah 
seringkali tidak ada pemisahan antara keuangan usaha dengan keuangan rumah tangga. Kondisi yang demikian seringkali menjadi awal kredit macet karena pelaku usaha tidak bisa mengontol keuangannya sebagai dampak tidak adanya pencatatan dan pengelolaan keuangan yang baik. Memperhatikan permasalahan yang demikian, tim pengabdian Universitas Sebelas Maret tergerak untuk memberikan pelatihan pengelolaan keuangan secara sederhana yang disesuaikan dengan kapasitas peserta. Materi yang diberikan dalam pelatihan ini adalah tentang pentingnya laporan keuangan bagi perusaahaan, tatacara pencatatan transaksi usaha dan teknis pembuatan laporan keuangan bagi Usaha Kecil dan Menengah.

Laporan keuangan,merupakan laporan kinerja usaha yang terpenting. Dengan melihat laporan keuangan pihak kreditor dapat menilai perkembangan kinerja usaha dan dapat mengestimasi kinerja usaha di masa yang akan datang. Untuk bisa berkembang dengan baik pengusaha kecil dan menengah harus bisa menyusun dan menyajikan laporan keuangan dengan benar. .Para pelaku usaha harus melakukan pencatatan transaksi usaha yaitu kegiatan mencatat setiap transaksi yang berhubungan dengan kegiatan usaha untuk dapat menyusun dan menyajikan laporan keuangan. Secara standar, transaksi yang perlu dicatat adalah transaksi yang berhubungan dengan: kas, pembelian (tunai dan kredit), penjualan (tunai dan kredit) dan piutang, dan utang.

Pembuatan laporan keuangan tidak akan terlepas dari neraca dan laporan laba/rugi (Income Statement). Neraca merupakan laporan keuangan yang menyajikan data terkait harta, utang, dan modal perusahaan pada waktu tertentu secara seimbang. Keseimbangan neraca dapat ketahui apabila harta perusahaan jumlahnya sama dengan utang yang ditambah modal $($ Harta $=$ utang + modal $)$. Bagi perusahaan neraca dapat digunakan sebagai alat evaluasi terkait struktur modal dan ukuran tingkat pengembalian. Melalui neraca perusahaan juga dapat mengetahui solvabilitas, fleksibilitas maupun likuiditas. Untuk mengukur keberhasilan operasi perusahaan selama periode tertentu, perusahaan dapat melihat laporan laba/rugi.. Melalui laporan ini perusahaan dapat mengetahui kinerja operasi perusahaan, apakah menguntungkan atau sebaliknya. Dalam laporan laba/rugi dapat diketahui penjualan bersih dan biaya yang dikeluarkan selama periode tertentu. Apabila total pendapatan lebih besar dari total biaya maka perusahaan dikatakan untung dan dikatakan rugi apabila terjadi sebaliknya perusahaan dikatakan rugi karena total biaya lebih besar dari pendapatan.

\section{Memperkuat Branding Produk Melalui Kemasan}

Desain dan kemasan merupakan dua hal penting dalam pemasaran suatu produk. Dalam pemasaran, kemasan seringkali menjadi penentu suatu produk diterima oleh konsumen atau tidak. Secara definisi, kemasan adalah bahan yang digunakan untuk mewadahi dan/atau membungkus pangan, baik yang bersentuhan langsung dengan pangan maupun tidak (UU No.7 Tahun 1996 tentang Pangan). Desain kemasan adalah visual perwajahan, bentuk, bahan, dan pencitraan yang ingin ditampilkan pada sebuah kemasan untuk meningkatkan performa produk. Bagi produk, kemasan bukan sekedar sebagai pembungkus semata, tetapi berperan juga sebagai alat bantu pemasaran, pencitraan produk, menampilkan identitas, legalitas, dan sebagai sumber informasi produk kepada konsumen. Kemasan tidak sekedar berfungsi sebagai pengemas dan pelindung tetapi juga sebagai identitas produk, legalitas dan informasi produk, serta alat bantu pemasaran produk. Keseluruhan peran tersebut akan membentuk citra produk

Dalam kegiatan pengabdian ini peserta pelatihan diberikan materi tentang kemasan yang sangat bermanfaat untuk meningkatkan penjualan dan memenangkan persaingan. Dengan topik memperkuat daya saing produk melalui desain kemasan, narasumber memberikan pemahaman tentang bagaimana mendesain dan membuat kemasan yang marketable. Narasumber memberikan banyak informasi terkait kemasan, seperti membuat desain kemasan, jenis bahan kemasan serta beberapa elemen desain kemasan yang harus dipahami oleh peserta. Selain itu, peserta pelatihan juga mendapat penjelasan tentang fungsi, manfaat dan contoh kemasan baik kemasan primer, kemasan sekunder dan kemasan tersier. Selain memberikan pelatihan tentang cara mendesain dan membuat kemasan yang mempunyai daya saing dan marketable, narasumber juga mereview desain dan kemasan yang sudah digunakan peserta pelatihan. Diharapkan dengan mengetahui kekurangan dan kesalahanan desain dan kemasannya, peserta pelatihan dapat memperbaiki agar produk lebih mempunyai daya saing dan marketable. 


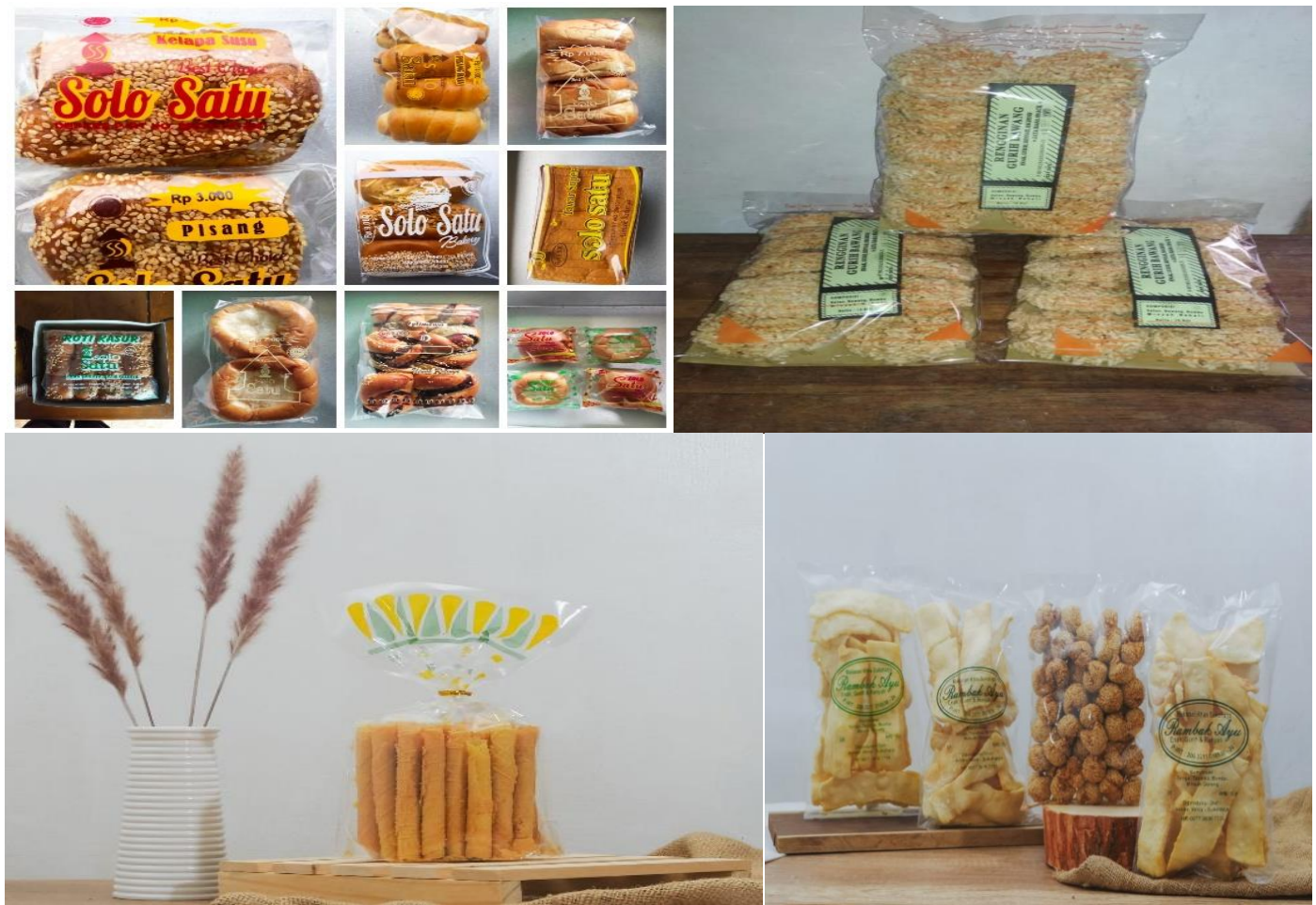

Gambar 1. Kemasan produk anggota Koperasi Pangan Boga Makmur yang kurang marketable

Salah satu produk yang dihasilkan oleh anggota Koperasi Pangan Boga Makmur adalah roti dengan merek Solo Satu sebagaimana tersaji dalam Gambar 1. Apabila dilihat sepintas, desain kemasan roti Solo Satu ini menarik dan marketable. Namun apabila diperhatikan secara detail, dapat diketahui bahwa ada ketidakkonsistenan dalam menggunakan desain merek dan kemasan. Gambar 1 memperlihatkan bentuk huruf dan warna yang berbeda-beda pada merk kemasan roti Solo Satu. Dalam pemasaran, tidak konsisten dalam menggunakan desain merek dan kemasan menyebabkan produk tidak diingat secara baik oleh konsumen. Apabila produk tidak tersimpan lekat di benak konsumen maka permintan produk tersebut akan minimal dan tentu saja pendapatannya rendah. Selain desain merek dan kemasan roti Solo Satu yang tidak konsisten, beberapa produk dari anggota Koperasi Pangan Boga Makmur masih dikemas dengan sederhana dan kurang marketable sebagaimana tersaji dalam Gambar 1.

Kemasan yang marketable sangat diperlukan karena dalam pemasaran produk terutama terkait pangan kemasan adalah hal yang pertama dinilai oleh konsumen. Kemasan yang menarik akan memberi keyakinan kepada konsumen bahwa produk yang ditawarkan berkualitas dan memenuhi harapan konsumen. Gambar 2 merupakan kemasan yang digunakan oleh anggota Koperasi Pangan Boga Makmur yang dijadikan contoh sebagai kemasan yang marketable dan mempunyai daya saing. Kemasan kacang bawang dalam Gambar 2 merupakan kemasan yang lebih mengedepankan jenis produk. Tulisan "kacang bawang" yang cukup besar dan dengan warna yang kontras akan menarik konsumen. Dengan kemasan plastik bening tebal yang membuat kacang bawang terlihat dengan jelas dapat menggoda konsumen untuk membeli. Apabila rasa memang bisa diandalkan maka merek "Bu Jasmin" akan diingat oleh konsumen ketika akan membeli produk yang sama. Kemasan kedua yang digunakan sebagai contoh kepada peserta pelatihan terkait kemasan yang marketable dan mempunyai daya saing adalah kemasan "Peyek bunder". Sebagaimana kacang bawang, kemasan yang digunakan dalam peyek bunder ini mengedepankan produknya. Dengan desain kemasan yang menarik dan tampilan produk yang menggoda selera, kemasan peyek bunder ini marketable dan mempunyai daya saing. 

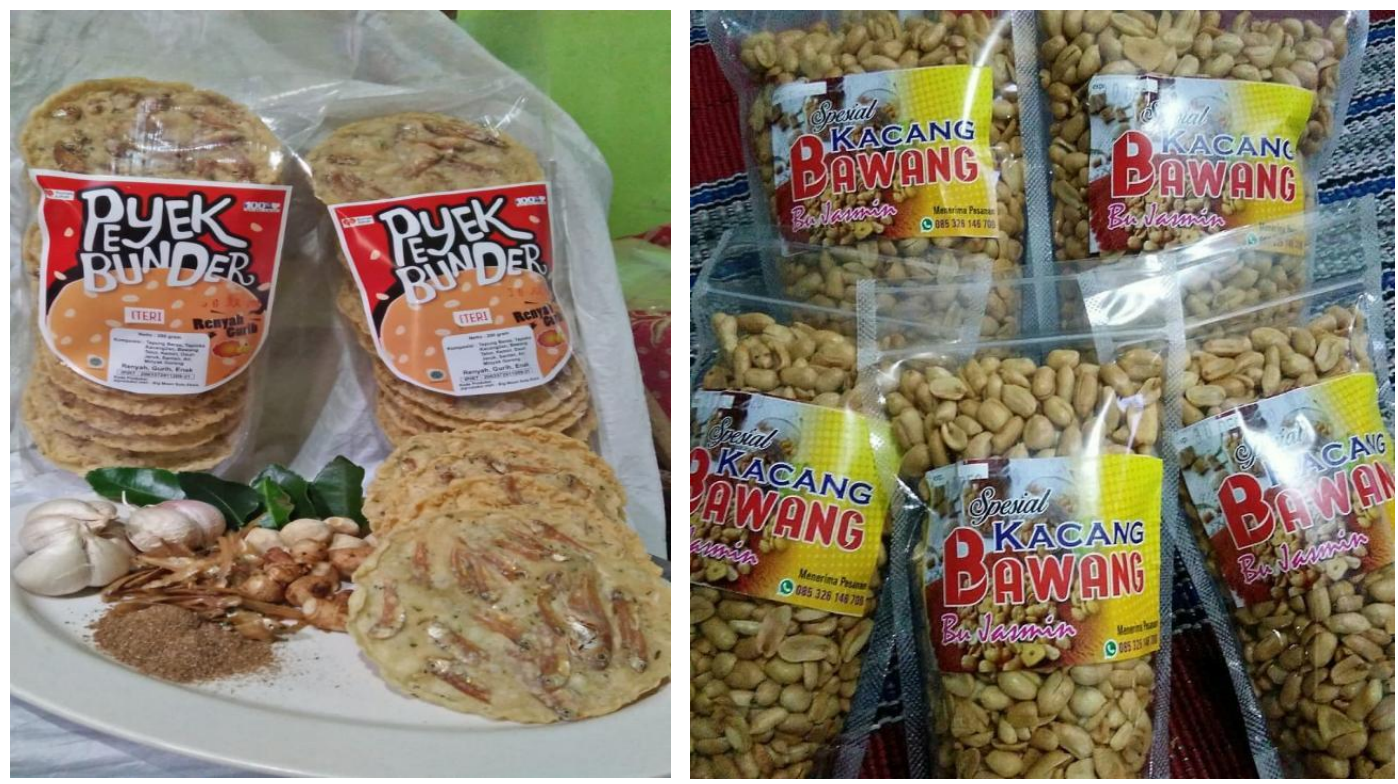

Gambar 2. Kemasan produk Anggota Koperasi Pangan Boga Makmur yang sudah marketable

\section{Monitoring dan evaluasi}

Dalam sebuah pelatihan, monitoring dan evaluasi mutlak dilakukan untuk mengetahui sejauh mana pelatihan yang diberikan kepada peserta memberikan manfaat. Dalam situasi pandemi dimana semua pihak harus meminimalisir berkumpul dan berkerumun, monitoring dilakukan secara daring. Hasil monitoring menunjukkan bahwa sebagian besar peserta belum menerapkan apa yang diperoleh dalam pelatihan. Hanya sekitar $10 \%$ yang mulai mengaplikasikan materi pelatihan terkait pembukuan keuangan dan 30\% yang sudah mempunyai kemasan yang marketable. Hal ini dikarenakan usaha mereka banyak yang mati suri sebagai dampak pandemi. Selama ini konsumen utama mereka adalah wisatawan, hajatan ataupun pertemuan-pertemuan baik yang diadakan di kantor-kantor ataupun hotel. Dengan adanya pembatasan dalam rangka memutus rantai penyebaran virus, permintaan produk mengalami penurunan yang luar biasa. Kondisi ini menyebabkan sebagian besar dari peserta pelatihan belum bisa mengaplikasikan materi pelatihan. Berdasarkan hasil monitoring dan evaluasi yang dilakukan secara daring dapat diketahui bahwa semua peserta pelatihan memahami dan merasakan adanya manfaat mengikuti pelatihan. Setelah kondisi membaik, diharapkan sebagian besar peserta pelatihan bisa mengaplikasikan materi yang diberikan dalam pelatihan untuk meningkatkan kapasitas.

\section{KESIMPULAN}

Dari hasil kegiatan pengabdian di Koperasi Pangan Boga Makmur dapat disimpulkan bahwa pelatihan ini sangat bermanfaat bagi peserta. Peserta mendapatkan pemahaman tentang desain kemasan yang marketable dan cara pembukuan keuangan yang benar. Namun adanya pandemi yang menyebabkan usaha mereka terhenti menyebabkan belum semua peserta pelatihan bisa mengaplikasikan materi yang diberikan. Dari hasil monitoring dapat diketahui dari 14 peserta pelatihan, baru sekitar $10 \%$ yang sudah melakukan pembukuan dan $30 \%$ yang telah mempunyai kemasan yang marketable. Walaupun saat ini materi pelatihan belum sepenuhnya bisa diaplikasikan karena kondisi pandemi diharapkan pelatihan tetap memberikan manfaat bagi peserta di masa yang akan datang.

\section{UCAPAN TERIMA KASIH}

Terlaksananya kegiatan pengabdian ini karena dukungan berbagai pihak. Untuk itu tim pengabdian mengucapkan terima kasih kepada Lembaga Penelitian dan Pengabdian kepada Masyarakat Universitas Sebelas Maret yang telah memberikan hibah skim pengabdian dengan Program Kemitraan Masyarakat Tahun 2020. Ucapan terima kasih juga disampaikan kepada ketua dan anggota Koperasi Pangan Boga Makmur dan mitra yang berperan aktif dalam pelatihan sehingga kegiatan dapat berjalan dengan baik dan lancar. 


\section{DAFTAR PUSTAKA}

Afiyanti, Y. (2008). Focus group discussion (diskusi kelompok terfokus) sebagai metode pengumpulan data penelitian kualitatif. Jurnal Keperawatan Indonesia, 12(1), $58-62$. https://doi.org/10.7454/jki.v12i1.201

Ambarwati, M. (2015). Pengaruh citra merek terhadap minat beli (survei pada mahasiswa Universitas Brawijaya yang menggunakan pasta gigi pepsodent). Jurnal Administrasi Bisnis S1 Universitas Brawijaya, 25(1), 86141.

Anisa, R. (2017). Pengaruh kemasan produk dan merk teh celup. Jurnal Manajemen Dan Kewirausahaan, 2(2), 78-88.

Anwar, K., \& Fatmawati. (2018). Pengaruh jumlah penduduk usia produktif, kemiskinan dan inflasi terhadap pertumbuhan ekonomi di Kabupaten Bireuen. Jurnal Ekonomi Regional Unimal, 01(01), 15-22.

Bismala, L. (2016). Model anajemen usaha mikro kecil dan menengah (UMKM) untuk meningkatkan efektivitas usaha kecil menengah. Jurnal Enterpreuner Dan Enterpreneurship, 5(1), 19-25.

BPS. (2016). Potensi peningkatan kinerja usaha mikro kecil. Badan Pusat Statistik.

Erijanto, A. C., \& Fibrianto, K. (2018). Variasi kemasan terhadap tingkat kesukaan dan pengambilan keputusan konsumen pada pembelian makanan tradisional: kajian pustaka. Jurnal Pangan Dan Agroindustri, 6(1), 91-96. https://doi.org/10.21776/ub.jpa.2018.006. 01.11

Hadiyati, E. (2011). Kreativitas dan inovasi berpengaruh terhadap kewirausahaan usaha kecil. Jurnal Manajemen Dan Kewirausahaan, 13(1). https://doi.org/10.9744/jmk.13.1.8-16

Hamdan, H. (2018). Industri 4.0: pengaruh revolusi industri pada kewirausahaan demi kemandirian ekonomi. Jurnal
Nusantara Aplikasi Manajemen Bisnis, 3(2), 1. https://doi.org/10.29407/nusamba.v3i2.1 2142

Hartono, H., \& Hartomo, D. D. (2016). Faktorfaktor yang mempengaruhi perkembangan umkm di Surakarta. Jurnal Bisnis Dan Manajemen, 14(1), 15. https://doi.org/10.20961/jbm.v14i1.2678

Kementerian Koperasi dan UKM. (2017). Laporan kinerja kementerian koperasi dan usaha kecil dan menengah tahun 2017. Kementerian Koperasi dan UKM.

Kementerian Koperasi dan UKM. (2019). Laporan kinerja kementerian koperasi dan usaha kecil dan menengah Republik ndonesia tahun 2018. Kementerian Koperasi dan UKM.

Lidyasuwanti, A. (2017). Pengaruh kemasan, brand image dan brand trust terhadap minat beli konsumen pada produk pancake durian sharie radjanya di Kota Mataram. Jmm Unram - Master of Management Journal, 6(2), 1-17. https://doi.org/10.29303/jmm.v6i2.105

Munizu, M. (2013). Strategi peningkatan kinerja dan peran usaha kecil. Manajemen \& Bisnis, 12(1), 101-110.

Rohida, L. (2018). Pengaruh era revolusi industri 4.0 terhadap kompetensi sumber daya manusia. Jurnal Manajemen Dan Bisnis Indonesia, 6(1), 114-136. https://doi.org/10.31843/jmbi.v6i1.187

Sidu, D., \& Sugihen, B. G. (2007). Pemberdayaan masyarakat sekitar kawasan hutan lindung jompi Kabupaten Muna, Provinsi Sulawesi Tenggara. Jurnal Penyuluhan, 3(1). https://doi.org/10.25015/penyuluhan.v3i1 .2146

Tunky, H., \& Kohardinata, C. (2016). Perancangan desain kemasan pada merk keripik pisang bananation di Surabaya. Jurnal Manajemen Dan Start-Up Bisnis, 1(1), 567-583. 